\title{
Globalization and the Challenge of Industrialization in Developing Nations: The Nigeria Experience
}

\author{
Agba, A. M. Ogaboh ${ }^{1}$ and Emmanuel Odu ${ }^{2}$ \\ ${ }^{1}$ Lecturers, Department of sociology, University of Calabar, Calabar, Nigeria. \\ ${ }^{2}$ Lecturers, IPPA, University of Calabar, Calabar, Nigeria.
}

\begin{abstract}
The paper examines the impact of globalization on industrialization in developing countries with particular reference to Nigeria. We considered the effect of economic liberalization on indigenous and modern industries in Nigeria; and x-rayed the impact of globalization on government industrial policies. The study acknowledged that, factors such as physical infrastructure, corruption, finance, policies inconsistency among others militate against industrial development in Nigeria but argued that globalization do even more. We posit that globalization made Nigeria a huge market for finished goods from developed economies and conditioned the country's economy in to consuming one. We recommended among others the adoption of a radical industrial policy that would revolutionize indigenous and modern industries in Nigeria and nurture them to a level where they can favorably compete with transnational corporations operating within the country and elsewhere in Africa. We argue that except this radical step is taken, Nigeria would continually be neo-colonized and conditioned by advanced economies/ nations.
\end{abstract}

Keywords: Globalization, industrialization, developing nations, indigenous industries.

\section{Introduction}

Globalization is a household word that has attracted divergent comments and opinions globally. The word "globalization" is derived from the verb "globalize", which means "to make worldwide in scope" (Mugabe, 2002:1). It is technological advances that have ease international transactions, in trade and financial markets. It reflects the "press of denationalization of markets, politics and legal system" for the emergence of global economy (Czenter, 2002:7). It includes the emergence of worldwide interdependence among nations propelled by the "unprecedented contraction of space and time occasioned by" advances in information and communication technology (ICT) and the new revolution in transportation technology (Anyakoha, 2003). It involves the creation of a new world order with a clear geo-political and economic "domination strategy which neatly divides the world into 'North' and 'south' while at the same time loudly proclaiming the advent of one world" (Mugabe, 2002:1).

Globalization directly or indirectly affects the socio-economic and political development of nations. It stimulates and leapfrogs technological advancement in developing countries (Mbanefoh, 2002). Globalization is view by some scholars as beneficial, inevitable and irreversible; while others belief that it increases inequality within and among nations, creates unemployment and threatens social security and progress (Czenter, 2002). This implies that globalization offers opportunities and threats to most nations of sub-Saharan Africa (Mugabe, 2002).

Divergent opinion exists on how well developing nations especially in sub-Saharan Africa are involved in the integration of world economies. This is because globalization is a multisided process with great capacity to change the path of history in many nations (Cap, 2002). Czenter (2002) argue that the process of developing nations catching up with advanced nations in a globalized economy differed "in intensity from region to region". Asia countries are making remarkable progress in the journey of catching up with developed nations; however in most countries of Africa, the progress is slow and some have lost grounds. Efemini (2003) posit that globalization affects different regions and countries differently and Nigeria is not among the favoured ones.

Although studies on the effect of globalization on other facet of the Nigerian society receive much currency, its effect on industrial development receives less enthusiasm. Our concern in this paper therefore is to examine the impact of globalization on industrialization in Nigeria. Specifically we would consider the challenges globalization pose to industrialization; and ex-ray its effect on indigenous industries. Consequently, the rest of this study would be organized under the following sub-heading:

1. Theoretical consideration 
2. Historical antecedence of globalization

3. Benefits and threats of globalization.

4. Globalization and the evolution of industrial policies in Nigeria

5. Globalization and indigenous industries

6. Globalization and the challenge of modern industries in Nigeria

7. Other challenges of industrialization in Nigeria

8. Conclusion

\section{Theoretical Consideration}

A number of theories attempted to explain the origin and effect of industrialization in different societies. The general application or the empirical relevance of some of the theories remains problematic; for instance the Protestant Ethics and the Spirit of Capitalism by Max Weber could only explain the influence of religious ideas on economy and the origin of industrialization in Europe especially Britain. Its empirical relevance to the Nigerian situation is underscore. However in this study, we attempt to explain globalization and industrial backwardness of Nigeria within the theoretical framework of Dialectical Materialism as proposed by Karl Marx.

In this theory, Marx view change as the struggle of the opposite, that is conflict provides the dynamic principle of history. Social change in this regards including (industrialization and globalization) are products of the continuous struggle between incompatible forces; in this instance (the struggle between the less advanced nations and the advanced nation). Marx argues that history begins when man produce material life. He posits that the major contradiction or incompatible forces that propel social change are "found in the economic infrastructure of society" (Haralambos, Holborn \& Heald, 2004:945).

Idyorough (2002) have argue that to use dialectic theory to explain the new economic order in modern Nigeria (especially industrialization and globalization) is to understand first the role international capital and mega corporations plays in developing nations. He argues that, the large scale production of goods and service by giant multinationals has turned the world in to a global village. In the same vein, the international capital has turned the globe into a world market, were produce from mega corporations are bought and sold. The innovation in information communication technology (ICT) and the advances in transportation technology propel global interactions. This discovery "have made all other nations peripheral nations dependent on the core nations for the supply of goods and services" (124). Globalization in this regard places the resources/means of production in developing nations in the hands of giant multinational corporations.

The unequal relationship between the advanced society and Nigeria has placed the country into a perpetual dependent nation, and a buyer of goods and services from advanced countries. It has made Nigeria a market place (not a producer) whose price system is determined by core nations (Idyorough, 2002). The entire industrialization process in the country is control in favour of the metropolitan nations, to the detriment of home grown technology. The unfavourable relationship between the rich and poor countries continually stagnate indigenous industries in developing countries including Nigeria. Within the Marxian paradigm the only solution to Nigeria's industrialization problem is the radical and violent breakout from the organized capitalist industrial system dominated by advanced economies of Europe and America. It also calls for the overthrowing of the capitalist industrial complex and enthronement of indigenous industries patterned after the Nigerian system and control by Nigerians.

\section{Historical Antecedence of Globalization}

There are conflicting or almost complementary views about the origin of globalization. We attempt to synthesize these views and present a chronological history of globalization. Globalization which include denationalization, delocalization, high level of economic internationalization, hyper flexibility and hyper mobility of goods (including human labour/commodity) and services has a long historical antecedence (Cap, 2002; Shaka, 2003). Globalization could be traced back to the ancient civilizations where empires trade among themselves. Historical evidence shows that there was trade links between the Sumerian Civilization and the Indus Valley Civilization in the third millennium B. C. This was followed by other trade relationship between countries of Greece, Roman Empire, India and Parthian Empire. These various trade routes and interactions informed the establishment of international trade law (http://business.map ofindia.com/globalization/history.html). The trade between these empires was made possible by the production of surplus goods/commodity that needed foreign markets. Thus, the search for new markets as a result of surplus commodity marks the origin of globalization.

Globalization could also be traced to the emergence of new type of production system that replaces the 800 years old feudal system (agriculture era). The invention of steam engine in the $18^{\text {th }}$ century made this revolution possible (Thurrow, 2003). During the agriculture era, "nation states existed quite independently of one another, having little relationship with each other". The advances in forces of production occasioned by the 
first industrial revolution (steam engine), brought remarkable increase in goods and services which gradually went beyond national boundaries (Cap, 2002:243).

The second industrial revolution based on the invention of electricity further expands the horizon of internationalization, as the economic path of countries was again altered commodity in the market increased even more beyond national boundaries. The third industrial revolution (the invention) of micro-electronics, computers, telecommunications, robotics, and biotechnology accelerated world trade and the globalization of world events (Thurrow, 2003). Kar/Marx and Fredrick Engels in the "community manifesto have argue that "modern industry has established the world market, which the discovery of America pave the way". Similarly, Lindert and Williamson (2001) posit that the voyage of Columbus and de Gama from Europe to other parts of the world more than 500 year ago marks the internationalization of trade and culture. Amin (2000) and Cap (2002), argue that advances in naval technology in the $15^{\text {th }}$ and $16^{\text {th }}$ centuries encouraged the geographical expansions and the discovery of new markets for the surplus goods of Europe. The exploitation of the world market by the bourgeoisie gave a cosmopolitan attribute to world trade and the production of goods and services.

\section{Benefits and Threats of Globalization}

There are divide debates about globalization; some in favour of while others against. According to Babatude (2003: viii) "globalization is a term which is hated by many but loved by probably more people in many more countries all over the world." Anyakoha (2003) argue that globalization creates opportunities and poverty, it affect people lives positively and negatively. Singl (2007) observed that liberalized global economy encouraged free trade, free capital flow and domestics' labour market flexibility rather than free international movement of employees. Consequently, it could be favourable as well as unfavourable depending on time and space. Globalization in this regards stimulate unparalleled prosperity among nations and could enhance workers' wages in rich and poor countries alike.

Globalization expands real choices and accelerates technological progress. It encourages the free movement or transfer of technology among nations and could help backward nations to catch up with advanced ones. Mugabe (2002) observes that globalization offers opportunities for fundamental scientific research collaboration as well as ease the transfer of technology between developed and developing nations. However, UKaegbu (1991) argue that such collaboration especially in the area of technology transfer is often superficial and may not stimulate industrialization in developing countries. It is also said, that globalization promotes efficiency in industries through competition. Raw in Anyakoha (2003) have argue that such competition many times leads to the taking over of weaker companies in developing countries by mega ones from advanced economics, leading to unemployment, neo-colonialism and huge repatriation of resources from the periphery to the centre.

\section{Globalization and the Evolution of Industrial Policies in Nigeria}

The centrality of industrialization to national economic development has informed a number of policies geared towards making Nigeria an industrialized nation. Famade (2009) observes that the first industrial strategy embarked upon in Nigeria was aim at reducing over-dependence on foreign trade and save foreign exchange by encouraging the production of good that were formally imported. This policy was meant to save the country from being a dumping ground for surplus goods from advanced economies and against other negative impacts of globalization. However, the poor implementation of the policy occasioned the emergence of other industrial policies including the indigenization policy of 1972 and 1977.

The indigenization policies of 1972 and 1977 were attempts by government to foster widespread ownership of industries among Nigerians. The indigenization policy was again another respond of government to the negative impact of globalization in Nigeria. It was meant to promote indigenous industries and create opportunities for Nigeria businessmen and women to take over the industrial sector of the country's economy. This includes the transfer of ownership and control from previous owners to Nigerians. However, the delocalization of business across the globe placed Nigeria economy in the hands of foreigners.

The indigenization policy was criticized by liberalists. Government in line with her critics, including institutions of globalization (International Monetary Fund-IMF and World Bank) introduced the Structural Adjustment Programme (SAP) in 1986 and the Trade and Financial Liberalization Policy (TFLP) in 1989. The former (SAP) was to promote investment and foster private sector driven economy. The later (TFLP) aimed at boosting competition among domestic and foreign firms as well as encourage efficiency in the financial sector. It was to promote foreign investment by reducing tariff and non-tariff barriers in the country. The implication of these policies to domestic firms is enormous. First the removal of tariff and non-tariff barriers promote foreign competition which was unfavourable to the country's ailing and vulnerable firms who were at their lowest level of production before the policy was introduced. Secondly, the privatization and commercialization exercise was 
ill-done; it rather encouraged the transfer of ownership of most domestic companies to foreign hands, thus reintroducing economy colonialism, the very objective of globalization.

The introduction of Bank for Industry (BOI) policy in 2000 was another step by government to promote industrial development in Nigeria. Banks such as Nigerian Industrial Development Bank, Leasing Company of Nigerian Limited, Industrial and Insurance Broker and Nigerian Bank for Commerce and Industry were established to provide equity, loans and enhance financial access to industries in Nigeria. However, the objectives of these Banks are yet to be realized because of bureaucratic bottle nicks that characterized their operations. Thus Nigerian indigenous firms cannot adequately access funds and as such cannot compete favourably with other trans-national companies.

Globalization is arguable one of the major factors that increases inequality among nations and threaten employment (http://www.inf.org/external/np/exr/ib/2001/041 200.htm). The skyrocketing unemployment in Nigeria is not unconnected to the collapse of domestic industries. In attempt to create employment and enhance the performance of domestic firms as well as expand diversification in the industrial sector, government in 2000 established Small and Medium Industries Equity Investment Scheme. To support the scheme government introduced a number of incentives including - tax holidays of at least five years, import duty relief, duty drawback scheme, total ban on certain foreign goods, reduction of exercise duty, provision of loans, exports incentives etc. Other institutional framework to promote industrial development in Nigeria includes the establishment of special industrial development institutes and councils, example the Raw Material Research and Development Council and the Federal Institute of Industrial Research.

The history therefore of industrial policies in Nigeria has been a reflection of the scenario in the international arena. Some of the policies were meant to support globalization while others challenged its trend in Nigeria. The dynamic of these policies is itself, a constrained to industrialization in Nigeria, this suggests that government should rethink before embarking on any other reform.

\section{Globalization and Indigenous Industries}

Indigenous industries or what some scholars' term indigenous technology has a long history in Nigeria before the advent of colonialism. The various empires, kingdoms and nations that formed the present Nigeria, were major centres for blacksmith, weaving and pottery-making. Olaoye (1987) observe that the Kano cloth industry, the hand woven cloths and the black and red earthenware pottery industries in Ilorin were among the indigenous industries that enjoyed great patronage during the $19^{\text {th }}$ century.

Oyama, Ogoni and Okoronkwo (2006) also gave account of indigenous industries that existed among the Gwari people of Abuja. They posit that the Gwari people are known for their traditional iron mining and smelting. The industry produced items such as farming hoes, hammers, and cutlasses. Similarly, Petters, Iwok and Uya (1994) enumerated a number of indigenous industries in the South-South States of Nigeria with particular reference to Akwa Ibom State, these include -carved doors and furniture industry, the bamboo furniture industry, mat making industry, canes crafts, raffia craft and basketry industries. Others are pottery crafts industry, smiting and metal crafts and weaving industries. Remarkably, the smiting and metal crafts industry engaged in the production of machetes, chisels, pan pots, metal boxes, and metal furniture, gates and beds.

Indigenous industries that characterized the $19^{\text {th }}$ century empires, kingdoms and nations in Nigeria dwindle with globalization. This is because globalization destroys value systems of weaker societies. Anyakoha (2003:4) have argued that "globalization is the offensive and oppressive march of international capitalism and the destruction of cherished value in it makes everywhere". Globalization in this regards reflect ideological, economic, political and cultural conquest of the weaker nations by the advanced capitalist and imperialist nations. In others words, globalization thwarts social progress and increases human misery (http://www.inforg/external/np/exr/ib/2000/041'200.htm).

Indigenous industries in Nigeria are destroyed by the surplus goods produce from industrialized nations of Europe, Japan, China, and Britain etc. The consumption patterns of Nigerians is altered by globalization, people today prefer western goods at the expense of indigenous ones. Since there is low/poor market for local goods, indigenous industries are discouraged from producing, resulting to their closure. Attempts by successive government to salvage indigenous firms through industrial policies have failed due to lack of sincerity of purpose and political will, as well as pressure from international communities interest in Nigerian market.

\section{Globalization and the Challenge of Modern Industries in Nigeria}

Modern industries are product of advances in science and technology. It depicts for now, the advanced stage by which inanimate energy or mechanical power replaces human energy in the course of production. These advances could be locally driven, transferred or even stolen from other countries. Globalization is arguable an agent of technological transfer from more advanced society to developing ones. The process or speed of such transfers differs and are uneven from one country to another, yet its impact is cumulative and 
could lead to a total transformation of the industrial sector of society. Ukaegbu (1991) argue that technology transfer that is informed by globalization is often superficial, overpriced and meant to repatriate huge profits from periphery to the centre.

Surprisingly, almost all the vibrant modern industries that operate in Nigeria as a result of globalization are multinational corporations (Agba \& Ushie, 2005). For instance, transnational corporations dominate the oil sector in Nigeria and these include Exxon Mobil Unlimited, Agip Petroleum Company, ELF Nigeria Limited, Total, Oando Oil, Chevron, Shall Petroleum Development Company (SPDC), Africa Petroleum (AP) among others (Agba, 2007). According to Ndebbio (2002) these mega-corporations are jointly responsible for the economic backwardness of the Niger Delta. Ukaegbu (1991) posit that these companies neglect indigenous production techniques or local content, and centralized their research and development facilities in their corporate headquarters outside Nigeria and could not possibly encourage the transfer of genuine technology to the country. Tanzer (1980) have argue that multinational oil companies are able to operate in Nigeria because they poses vital exploration technologies, muscle necessary capital and can afford the risk of petroleum and gas exploration; and are too strong for any indigenous company to possibly compete with them.

Agundu (2005), observe that globalization significantly enhanced America and United Kingdom foreign private investments in Nigeria. The trend, have continually globalized Nigeria into neo-colonization, slavery and economic backwardness. Only multinational companies such as Unilever, Volkswagen, Coca-Cola, and those in the oil sector flourished while the Nigeria owned modern firms who cannot stand foreign competition collapsed daily. The textiles, synthetic fabrics, soap and detergent, cement, sugar, paints, footwear and refineries (Fashola, 2004 \& Agbu, 2007) of the 1970s and 1980 are shot down and some privatized because of unfavourable competition from mega corporations.

The liberation and commercialization of the telecommunication sector lead to the fading away of the state run-firms including Nigerian Telecommunication Plc (NITEL), and Mobile Telecommunications Plc (MTEL). Since 2000, the revolution in the telecommunication industry is dominated by companies, such Globacom, Cisco, Multilinks, Rainbownet, Reltel etc (Agba, Ikoh, Ushie \& Bassey, 2010); most of these companies are owned by foreign investors. Although these companies help in increasing Nigeria's teledensity as well as create employment and enhance medical care and efficiency in the banking sector; we argue that these mega corporations are significantly responsible for the collapse of the Nigerian own companies. However, we do not underscore other factors that impede industrialization in Nigeria.

\section{Other Challenges of Industrialization in Nigeria}

Other impediments to industrialization apart from globalization are well documented in recent literature in Nigeria. Ukaegbu (1991) highlighted some of these factors to include lack of capital, poor management, corruption, inadequate technology, shortage of manpower, and lack of physical infrastructure such as transportation, telecommunication equipment, road network, water and electricity. For instance Ochiama (2007), Agba and Ushie (2009) posit that, Nigeria's per capita production of electricity dwindles as her population increases and cannot support industrial activities. The effects of epileptic and insufficient electricity supply in the country are grievous as most factories are close down, while small and medium enterprises (SMEs) are unable to effectively operate in Nigeria. Consequently, some firms are compelled to generate power and this not without consequence; it increases the cost of production and the final consumer bears the burden.

Corruption is also one of the most vital obstacles to industrialization in Nigeria. High level corruption among government official have enormous impact on infrastructural development in the country (Agba, Ikoh, Ushie \& Agba, 2008). Corruption threatens electricity supply in the country, it was widely reported that billions of Dollars was spent during President Obasanjo's tenure on power projects, and what Nigerians got in return was "blackout" while the bank accounts (both local and foreign) of contractors swollen (Agba, e tal, 2009). Corruption could also be responsible for the lack of adequate finance for the industrial sector, since monies from Banks for Industry (BOI) ends up in wrong hands.

However Ukaegbu (1991) argue that, lack of finance cannot necessary be a challenge to industrialization, since the number of Nigeria millionaires grew remarkably over the years; rather investors prefer commerce to industry. He also observes that inadequate labour is not impediment to industrial development, since many graduates in science, engineering and technical education are unemployed in Nigeria. Ukaegbu posit that the claim that inadequate physical infrastructure militate against industrialization is erroneous and a kind way of neglecting the fact that "infrastructure are the products, and not the agents of industrialization". These arguments strengthened our position in this paper that foreign competition and the superficial transfer of technology among others occasioned by globalization pose the greatest challenge to industrialization in Nigeria.

\section{Conclusion}


Globalization is a mixed gift to developing countries. It stimulates unparalleled development and could even more affect other sectors of developing economies negatively. Enormous literature abound in this divide debate, however in this study, our concern is on the impact of globalization on industrialization in developing economies with particular reference to Nigeria. We observed that economic liberalization affects indigenous and modern industries in Nigeria negatively. The study posits that globalization promotes foreign competitions that are unfavouable to Nigeria industries. We argue that despite the impediment, corruption, finance, and physical infrastructure such as electricity, water, road net-work posed to industrialization, globalization remains a single major challenge to industrial development in Nigeria. We also opinioned that globalization conditioned Nigeria into a consuming economy and the entire country as market for goods and services from advanced nations/economies. We recommend that for developing nations and indeed Nigeria to escape the scourge of globalization, radical industrial policies must be adopted by government that will provide conducive grounds and nurture the growth and development of indigenous and Nigeria own modern industries to a comparable level with those in/and from advanced economies. There should also be a paradigm shift from IMF and World Bank "tele-guide" industrial polices to indigenous and home-grown industrial polices.

\section{References}

[1]. Agba, A. M. O \& Ushie, M. A. (2005). Improving the Niger Delta Socio-Economic Status through Active Involvement of Multinational Corporations. Nigerian Journal of Social and Development Issues, 5 (1), 63-74.

[2]. Agba, A. M. O., Ikoh, M. U., Ushie, E. M. \& Agba, M. S. (2008). Bureaucratic Corruption in Nigeria: The Need for Institutional Reforms. Journal of International Politics and Development Studies, 4 (1 \& 2), 187-204.

[3]. Agba, A. M. O. \& Ushie, E. M. (2009). Nigeria at 50: Bugging Economic, Political and Sociological Issues. Journal of International Politics and Development Studies, 5 (2), 319-331.

[4]. Agba, A. M. O., Ushie, E. M., Ushie, M. A., Bassey, A. O. \& Agba, M. S. (2009). Human Development Trend in Nigeria: The Need for Concrete Implementation of the Seven Point Agenda. Nigerian Journal of Social and Development Issues, 6 (1), $15-28$.

[5]. Agba, A. M. O., Ikoh, M., Ushie, E. M. \& Bassey, A. O. (2010). Telecommunications Revolution: Implications on Criminality and Family Crisis in the South- South States of Nigeria. Computer and Information Science, 3 (1), 42-51.

[6]. Agbu, O. (2007). The Iron and Steel Industry and Nigeria's Industrialization: Exploring Cooperation with Japan. Series Paper No. 418 of Institute of Developing Economics, Japan External Trade Organization. Online available at: http://www.id.gojp/english/publish/download/vrf/pdf/418/pdf. Retrieved 1/10/11.

[7]. Agundu, P. U. C. (2005). Globalization and Transformation of the African Economy: Analysis of Foreign Investment Dynamics in Nigeria. Nigerian Journal of Social and Development Issues, 5 (1), 75-86.

[8]. Amin, S. (2000). Globalization and Capitalism's Second belle Époque. Radical Philosophy Review, 52 (2), 86-95.

[9]. Anyakoha, E. (2003). Positioning Nigeria for Development in an Era of Globalization: Challenges and Strategies. In M. O. Maduagwu \& V. C. Onu (eds.), Globalization and National Development in Nigeria. Bukuru: Fulbright Alumni Association of Nigeria.

[10]. Babatunde, G. M. (2003). Presidential Address on the occasion of the Fulbright Alumni Association of Nigeria Third Annual Conference, held at University of Nigeria, Nsukka.

[11]. Cap, C. V. (2002). Marx and Engles on Economic Globalization. Society and Thought, 15 (2), 241-245.

[12]. Czenter, A. (2002). Labour Market and Globalization: Human Resources Management in Global Enterprises. Published Dissertation of Centre International de Formation Europeanne, Institute European Des Hautes 'Etudes Internationales.

[13]. Efemini, A. (2003). Globalization and the Future of Democracy and Development in Nigeria. In M. O. Maduagwu \& V. C. Onu (eds.), Globalization and National Development in Nigeria. Bukuru: Fulbright Alumni Association of Nigeria.

[14]. Famade, O. O. (2009). Industrial Policies and Incentives in Nigeria Overtime. Online Available at http://www.com.ng/\# salient =pay$a b \& h l=\&$ source $=h p \& q i n d i g e n i z a t i o n$. Retrieved $16 / 9 / 11$.

[15]. Fashola, M. A. (2004). A Scheme for Nigeria's Optimal Industrial Development. In M. O. A. Adejugbe (ed.), Industrialization, Urbanization and Development in Nigeria. Lagos: Concept Publication.

[16]. Haralambos, M. Holborm, M. \& Heald, R. (2004). Sociology: Themes and Perspectives ( $6^{\text {th }}$ ed), London: Harper Collins.

[17]. Lindert, P. H. \& Williamson, J. G. (2001). "Globalization and Inequality: A Long History". Paper delivered at the World Bank Annual Bank Conference on Development Economics -Europe, Barcelona (June 25-27, 2001).

[18]. Idyorough, A. E. (2002). Sociological Analysis of Social Change in Contemporary Africa. Jos: Deka Publications.

[19]. http://www.business.mapsofindia.com/globalization/history.html. Retrieved 16/9/11.

[20]. http://www.info.org/external/np/exr/ib/2000/041200.htm. Retrieved 16/9/11.

[21]. Mbanefoh, G. (2002). Welcome address presented by the Vice-Chancellor, University of Nigeria, during the opening ceremony of the third annual conference and investiture of board of Trustees of the Fulbright Alumni Association of Nigeria (FAAN) on November 26, 2002 at Ikenga Hotel Ltd., Nsukka.

[22]. Mugabe, J. (2002). "The Impact of Globalization on Science and Technology in Sub-Saharan African Countries." African Technology Policy Studies Network (ATPS) Special Series Paper No. 3. Nairobi: ATPS

[23]. Ndebbio, J. E. U. (2002). The Role of Multinational Companies in the Economic Backwardness of the Niger Delta. Nigerian Journal of Social and Development Issues, 2 (1), 19-35.

[24]. Ndukwe, E. (2005. Three Years of GSM Revolution in Nigeria. Online available at: http://www.nce.ng/speches-presentation/Eve's. Retrieved 20/8/5

[25]. Ochiama, C. (2008), Yar'Adua's 7-point Agenda: A Performance Assessment. Online available at: http://nigerianfo.Blospotcom/2008/02/Yaraduas-7-pointagendaperformance.Html Retrieved 4/1/9

[26]. Olaoye, R. A. (1987). Indigenous Technology in Nigeria: A Case Study of the $19^{\text {th }}$ Century Ilorin Handicrafts. Paper presented at the $32^{\text {nd }}$ Congress of the Historical Society of Nigeria, May 10-15, 1987, in University of Jos, Nigeria.

[27]. Oyama, E. Ogonyi I. \& Okoronkwo, O. (2006). EL- Rufal and Abuja Urban Renewal Policies. UK: Crystal Print.

[28]. Petter, S. W., Iwok, E. R. \& Uya, O. E. (1994). Akwa Ibom State: The Land of Promise. Lagos: Gabumo Publishing Company Ltd.

[29]. Shaka, F. O. (2003). Nigerian History and Culture in a Global Context. In M. O. Maduawu \& V. C. Onu (eds.), Globalization and National Development in Nigeria. Bukuru: Fulbright Alumni Association of Nigeria. 
[30]. Signl, A. (2007). "Globalization, Industrial Revolutions in India and China and Labour Markets in Advanced Countries: Implications for National and International Economic Policy". Working papers No. 81 the Policy Integration Department, International Labour Office, Geneva.

[31]. Tanzer, M. (1980). “Oil Exploration Strategies: Alternatives for the Third World.” Capital Accumulation and Technology Transfer: A Comparative Analysis of Nigerian Manufacturing. New York: Praeger.

[32]. Thurrow, L. (2003). Fortune Favours the Bold: What we Must do to Build a New and Lasting Global Prospective. New York: Harper Collins.

[33]. Ukaegbu, C. C. (1991). The Structure of Nigeria Industries and the Utilization of Scientific and Technological Manpower. The Journal of Economic and Social Studies, 33 (1), unpaged. 